Araştırma

\title{
Yenidoğan Yoğun Bakım Ünitesi Ebeveyn-Personel İletişimi Algıları Ölçeği Türkçe Geçerlik ve Güvenirlik Çalışması
}

\author{
Hamide ZENGIN*, Öznur TİRYAKİ*, Özge KARAKAYA SUZAN***, Nursan ÇINAR***
}

\section{$\ddot{O} \mathbf{z}$}

Giriş: Ebeveynlerin Yenidoğan Yoğun Bakım Ünitesindeki (YYBÜ) bebeklerinin bakımına katılabilmeleri, onların yaşadıkları sürece uyum sağlamalarına, bebeklerinin durumları ile ilgili daha sağlıklı karar vermelerine ve sağlık ekibi ile iletişim içinde olmalarına katkı sağlar. Amaç: Bu çalışma Yenidoğan Yoğun Bakım Ünitesi Ebeveyn-Personel İletişimi Algıları Ölçeğinin (EPİAÖ-YYBÜ) Türkçe kültürel adaptasyonunu, geçerlik ve güvenirliğini yapmak amacıyla planlanmıştır. Yöntem: Araştırmanın örneklemini bir eğitim araştırma hastanesinin YYBÜ’sinde tedavi gören, araştırmaya katılmayı kabul eden ve sınırlamalara uyan, toplam 246 ebeveyn oluşturmuştur. Geçerlik kapsamında; kapsam geçerliği, açıklayıcı ve doğrulayıcı faktör analizleri, ölçek güvenirliği için; iç tutarlılık güvenirliği Cronbach Alfa katsayısı ve 25 kişiden oluşan bir örnek kullanılarak test-tekrar test için sınıf içi korelasyon (ICC) hesaplanmıştır. Bulgular: Ölçek maddeleri İngilizce'den Türkçe'ye çevrilerek dil ve kapsam geçerliği için uzman görüşüne sunulmuştur. Kapsam Geçerlik İndeksi ve Kapsam Geçerlik Oranlarının ortalaması 0,958 bulunmuştur. Açıklayıcı Faktör Analizi sonucunda Kaiser Meyer Olkin değeri 0,823; Doğrulayıcı Faktör Analizi sonucunda elde edilen uyum indeksleri $\left(\chi^{2} / \mathrm{sd}\right.$ : 3,068; RMSEA: 0,078; GFI: 0,873; CFI: 0,901; SRMR: 0,041) olarak elde edilmiştir. Uygulanan güvenirlik analizi sonucunda;16 maddeden oluşan EPİAÖ-YYBÜ'nün Cronbach Alfa katsayısı $(\alpha)$ : 0,926; 8 maddelik "Genel Engeller” alt boyutu için $\alpha$ : 0,876; 4 maddelik "Kişisel İlişkiler" alt boyutu için $\alpha:$ 0,901; 4 maddelik "Katılım" alt boyutu için $\alpha: 0,914$ olarak bulunmuştur. Test tekrar test sonucunda ICC katsayısı ölçek için 0,757 olarak tespit edilmiştir. Sonuç: Araştırma sonucuna göre, YYBÜ’sinde bebeği yatan ebeveynler ile personel arasındaki iletişim algılarının belirlenmesinde EPİAÖ-YYBÜ ölçeğinin Türk toplumu için geçerli ve güvenilir olduğu saptanmıştır. Anahtar Kelimeler: Yenidoğan Yoğun Bakım, İletişim, Ölçek, Geçerlilik ve Güvenilirlik.

\section{Abstract \\ Adaptation of the Perceptions of Parent-Staff Communication Scale-Neonatal Intensive Care Unitto Turkish: A Validity and Reliability Study}

Introduction: It can be ensured that parents can participate in the care of their babies in the Neonatal Intensive Care Unit (NICU), adapt to the process they live in, make a healthier decision about the health of the baby and communicate with the healthcare team. Aim: The aim of this research was to perform the Turkish cultural adaptation, validity and reliability studies of the Perceptions of Parent-Staff Communication in Neonatal Intensive Care Scale (PSCS-NICU). Methods: The sample of the study was included in the study, a total of 246 parents who were treated in the NICU of a training and research hospital, agreed to participate in the study and comply with the limitations. Content validity, exploratory and confirmatory factor analyses were calculated for validation. For the scale reliability, Cronbach Alpha coefficient and ICC were calculated for the test-retest using a sample consisting of 25 individuals. Results: The items of the scale were translated from English to Turkish and then presented to expert opinion for language validity. The average of the Content Validity Index and Content Validity Rates was found as 0.958 . Kaiser Meyer Olkin value was found to be 0.823 as a result of the exploratory factor analysis, and the fit indexes $\left(\chi^{2} / \mathrm{sd}: 3.068\right.$; RMSEA: 0.078; GFI: 0.873; CFI: 0.901; SRMR: 0.041) were obtained as a result of the Confirmatory Factor Analysis. As a result of the reliability analysis performed, it was found that Cronbach's Alpha coefficient of the scale consisting of 16 items was $\alpha$ : 0.926 , and that it was $\alpha: 0.876$ for the "General Barriers" sub-dimension consisting of 8 items, $\alpha: 0.90$ for the "Personal Relations" sub-dimension of 4 items and $\alpha$ : 0.914 for the "Participation" sub-dimension consisting of 4 items. The test-retest in-class correlation (ICC) coefficient was determined to be 0.757 for the whole scale. Conclusion: According to the results of the research, it was determined that the PSCS-NICU scale is valid and reliable for Turkish society in determining the communication perceptions between parents and personal in the NICU.

Keywords: Neonatal Intensive Care Unit, Communication, Scale, Validity, Reliability.

Geliş tarihi: 03.06.2020

Kabul tarihi: 31.03.2021

$\dot{\mathrm{I}}$ letişim, bakımda temel unsurlardandır (1). Sağlık personelinin hasta ve yakınları ile kurduğu iletişim sağlıkta iletişim olarak adlandırılmaktadır. Hasta ve yakınlarına karşı güven duygusunun oluşturulması, yardım edici tavır sergilenmesi, hasta ve yakınlarına belirsizlik hissi veren davranışlardan uzak durulması sağlık çalışanları ile hasta ve yakınları arasındaki anlaşmazlıkları ortadan kaldıracaktır. İletişimin sağlam temelli olabilmesi için hasta ve yakınına karşı empatik bir iletişim kurarak; dürüst, destekleyici ve eğitici olunmalıdır (2).

İletişim; sözlü ve sözsüz beceriler olarak sınıflandırılmasına rağmen sağlık alanında buna terapötik iletişim de eklenmektedir. Hasta ve yakınlarına mesai değişimlerinde hasta devri esnasında mesaiyi devralan personelin kendini tanıtması sözlü iletişim becerisidir. Bu durumda herhangi bir sıkıntı veya endişeli bir durumda kişinin ne yapması gerektiğini bilmesini sağlayacak ve bireylerde oluşan güvensizlik ve belirsizlik sorunu büyük oranda ortadan kalkacaktır. Yine sağlık çalışanlarının mesajlarını beden dili, vurgu ve mesafe gibi yollarla hasta ve yakınlarına aktarması da sözsüz iletişim becerisidir (3-5). Hasta ve yakınları ile sağlık personeli arasında yapıcı, olumlu, hasta ve yakınının güven duyacağı şekilde bir ilişki oluşturulması da terapötik iletişim becerisidir. Terapötik iletişim ayrıca "tedavi edici/yardım edici iletişim teknikleri ya da yardım becerileri" olarak da tanımlanmaktadır (6).

Yenidoğanlar bazı sağlık sorunları nedeniyle doğum sonu Yenidoğan Yoğun Bakım Ünitesi’ne (YYBÜ) transfer edilebilmektedir. Ebeveynler için bu durum, hazır olamadıkları ve stres oluşturan bir durum haline gelebilir.

*Dr. Öğretim Üyesi, Bilecik Şeyh Edebali Üniversitesi Sağlık Bilimleri Fakültesi, Çocuk Sağlığı ve Hastalıkları Hemşireliği Anabilim Dalı, Bilecik. ORCID: 0000-0002-2389-6466** Uzman Hemşire, Doktora Öğrencisi, Sakarya Üniversitesi Eğitim Araştırma Hastanesi, Sakarya Üniversitesi Sağlık Bilimleri Enstitüsü, Hemşirelik Doktora Programı, Sakarya. E-posta: oznuritiryaki@ gmail.com ORCID: 0000-0001-87883077 ***Araştırma Görevlisi, Doktora Öğrencisi, Sakarya Üniversitesi Sağlık Bilimleri Fakültesi, Çocuk Sağlı̆̆ ve Hastalıkları Hemşireliği Anabilim Dalı, Sakarya. ORCID: 0000-0003-4526-4619 **** Prof. Dr., Sakarya Üniversitesi Sağlık Bilimleri Fakültesi, Çocuk Sağlığı ve Hastalıkları Hemşireliği Anabilim Dalı, Sakarya. ORCID 0000-0003-3151-9975 
Araştırma

Doğumun beklenenden erken tarihte olması, YYBÜ’nin tıbbi cihazla kaplı, ürkütücü fiziki ortamı, alış1lmadık ses, 1şık ve görüntüler, bebeğin kaybedilme korkusu, bebekle etkileşime girememe, annenin bebeğini hastanede bırakarak taburcu olması, annenin bebek bakımında farklı beceriler geliştirmesi gerekliliği, ailenin hazır olmadan karşılaştığı bir durumdur $(7,8)$. Prematüre ve/veya sağlık sorunu olan bir yenidoğana sahip olmak, ebeveynlerin stres, anksiyete hatta destek sistemlerinin yetersizliği durumunda kriz potansiyeli yaratabilir (9).

Ebeveyn bu kadar karmaşık duygular içindeyken YYBÜ’nde çalışan sağlık personeli ile anlamlı bir iletişim kuramazsa bu süreç daha da karmaşık hale gelebilir. İran'da yapılan bir çalışmada ebeveyn-personel iletişimi ne kadar güçlü ise ebeveynlerdeki stresin daha düşük olduğu bulunmuştur (7). Bebeğin yenidoğan yoğun bakım ünitesinde bulunduğu dönem içerisinde ebeveynlerin, sağlık personellerinin hepsi ile (hekim, hemşire, hastane personeli) kurdukları etkili iletişim kendilerini daha anlaşılır bir şekilde ifade etmelerini sağlayacak, akıllarındaki belirsizlikleri ortadan kaldırabilecektir. Türkçe literatür incelendiğinde; YYBÜ'sinde bebeği yatan ebeveynlere yönelik "Hemşire-Ebeveyn Destek Ölçeği”ne rastlanmıştır (10). YYBÜ'nde çalışan hemşire dışında sağlık çalışanlarına yönelik ebeveynin iletişim algılarını ölçen bir çalışmaya ise rastlanmamıştır.

\section{Araştırmanın Amacı}

Bu çalışma; Yenidoğan Yoğun Bakım Ünitesi Ebeveyn-Personel İletişimi Algıları Ölçeğinin (EPİAÖ-YYBÜ) Türkçe kültürel adaptasyonunu, geçerlik ve güvenirliğini yapmak amacıyla planlanmıştır.

\section{Araştırma Sorulart}

Yenidoğan Yoğun Bakım Ünitesi Ebeveyn-Personel İletişimi Algıları Ölçeği, Türk toplumunda geçerli bir ölçek midir? Yenidoğan Yoğun Bakım Ünitesi Ebeveyn-Personel İletişimi Algıları Ölçeği, Türk toplumunda güvenilir bir ölçek midir?

\section{Araştırmanın Tipi}

\section{Yöntem}

Metadolojik tipte yapılan bir araştırmadır.

\section{Araştırmanın Yapıldı ğı Yer ve Tarihi}

Araştırma bir eğitim ve araştırma hastanesinin birinci, ikinci ve üçüncü basamak YYBÜ'de gerçekleştirilmiştir.

\section{Araştırmanın Evreni ve Örneklemi}

Araştırmanın evrenini Aralık 2017- Aralık 2019 tarihleri arasında bir eğitim ve araştırma hastanesinin YYBÜ'sinde bebeği yatan tüm (N:946) ebeveynler oluşturmuştur. Alan yazında; ölçek geliştirmede örneklem sayısının belirlenmesinde, ölçek madde sayısının ideal olarak 10 katı alınması önerilmektedir (11). Araştırmanın örneklem büyüklüğü, ölçek madde sayısının 10 katının alınması ilkesi doğrultusunda belirlenmiştir. Bu doğrultuda 21 maddeden oluşan "Yenidoğan Yoğun Bakım Ünitesi EbeveynPersonel İletişimi Algıları Ölçeği” taslağının 210 ebeveyne (10x21=210) uygulanmasına karar verilmiştir. Çalışmaya katılmayı kabul eden ve dahil olma kriterlerine (ebeveynlerin araştırmaya katılmaya gönüllü olması, en az ilkokul mezunu olması, iletişim probleminin olmaması, psikolojik probleminin olmaması) uygun 246 ebeveyn örneklem grubunu oluşturmuştur. Literatürde test tekrar testi için alınacak örneklemin, ana örneklemin en az \%10’u olacak şekilde olması gerektiği bildirilmiş olup, ölçeğin test tekrar testi 25 anne ile telefon ile görüşülerek yapılmıştır (12).

\section{Veri Toplama Araçları}

\section{Ebeveyn ve bebeklerinin tanttıcı bilgi formu}

Tanıtıcı bilgi formu ilgili literatür doğrultusunda araştırmacılar tarafından hazırlanmış olup, üç bölümden oluşmaktadır. İlk bölümde; anne ve baba yaşı, eğitim durumları, çalışma durumları, aile tipi, gelir düzeyi, yaşayan çocuk sayısı gibi soruları içermektedir. İkinci bölüm; annenin doğum şekli, gebelik sayısı, doğum esnasında/sonu problem yaşama durumunu, son bölümde ise YYBÜ'nde yatan bebeğin cinsiyeti, gestasyon haftası, tıbbi tanısı, beslenme şekli, konjenital anomalisinin olup/olmaması gibi sorular içermektedir.

\section{Yenidoğan Yoğun Bakım Ünitesi Ebeveyn-Personel İletişimi Algıları Ölçeği (EPİÄ̈-YYBÜ)}

Yenidoğan Yoğun Bakım Ünitesi Ebeveyn-Personel İletişimi Algıları Ölçeği (EPİAÖ-YYBÜ), Likert tipi, dörtlü derecelendirmeli (4= Kesinlikle Katılmıyorum, 3= Katılmıyorum, 2= Katılıyorum, 1= Kesinlikle Katılıyorum, 0=Deneyimlemedim) 27 maddeden oluşan bir ölçektir. EPİA-YYBÜ Ölçeği, ilk çalışma grubunda 535, ikinci çalışma grubunda 748 ebeveyne uygulanmıştır. Orijinal ölçekte yapılan açıklayıcı faktör analizi sonucunda üç faktörlü bir yapı elde edilmiştir. Genel Engeller (Madde 1, 2, 3, 4, 5, 6, 7, 8, 9, 10a,10b, 10c, 11b, 11c), Kişisel İlişkiler (Madde 12a, 12b, 12c, 13a, 13b, 13c, 14b, 14c) ve Katılım (11a, 14a, 15a, 15b, 15c) alt boyutlarından oluşmaktadır. Güvenirlik katsayısı birinci çalışma grubunda; tüm ölçek için: 0,89, Genel Engeller: 0,91, Kişisel İlişkiler: 0,86, Katılım: 0,84 olarak bulunmuş olup ikinci çalışma grubunda tüm ölçek için: 0,86, Genel Engeller: 0,89, Kişisel İlişkiler: 0,84, Katılım: 0,83 olarak rapor edilmiştir (1).

\section{Verilerin Toplanmast}

Araştırma verileri bir eğitim ve araştırma hastanesinin YYBÜ’nde bebeğini ziyarete gelen ebeveynlere, ziyaret sonrasında YYBÜ’nin görüşme odasında, araştırmacılar tarafından araştırma ile ilgili bilgi verildikten sonra, araştırmaya katılmayı kabul eden, çalışmaya dahil edilme kriterlerine uygun olan ebeveynlerden sadece biri (yalnızca anne ya da baba) çalışmaya alınmıştır. Araştırmacılar tarafından ebeveynlere bilgilendirilmiş yazılı onam ve veri toplama formu elden verilerek doldurmaları istenmiştir. Ebeveynlerin veri toplama formu ve ölçeği doldurmaları yaklaşı 10 dakika sürmüştür.

\section{Verilerin Değerlendirilmesi}

Araştırmada 246 katılımcıya ait veriler IBM SPSS Statistics 23 programına aktarılarak değerlendirilmiştir. Kategorik değişkenler için tanımlayıcı istatistikler (n, \%) verilmiştir. Uzmanların verdiği puanların değerlendirilmesinde Kapsam Geçerlik İndeksi ve Kapsam Geçerlik Oranı hesaplanmıştır.

Ölçeğin geçerlik ve güvenirlilik analizlerinde öncelikle Açıklayıcı Faktör Analizi çalışmalarına yer verilmiştir; daha sonra Doğrulayıcı Faktör Analizi çalışmaları ve son olarak faktörlerin iç tutarlılıklarını belirlemek amacıyla güvenilirlik analizi 
Araştırma

(Cronbach Alfa) ve test-tekrar testi yapılmıştır.

Çalışmanın açıklayıcı faktör analizleri ve güvenilirlik analizi çalışmaları SPSS 23.0 paket programı aracılığı ile hesaplanırken; doğrulayıcı faktör analizi AMOS 22.0 yazılımı ile gerçekleştirilmiştir. Tüm istatistiksel analizlerde anlamlılık düzeyi p <0,05 olarak kabul edilmiştir. Test-tekrar test güvenirliğinin değerlendirilmesinde Sınıf İçi Korelasyon (ICC) katsayısı kullanılmıştır.

\section{Ölçek Dil Geçerliliği}

Dil geçerliliği için, öncelikle ölçeği geliştiren yazarlardan biri olan Tilly Reid ile iletişim kurularak elektronik posta yoluyla izin alınmıştır. Bununla birlikte ölçek maddelerinin Türkçeye çevirisi yapılırken, dildeki en uygun cümle yapısının, deyimlerin kullanılmasına dikkat edilmesi göz önünde bulundurularak; ilk aşamada ölçek, Türkçe ve İngilizce'yi iyi bilen Çocuk Sağlığı ve Hastalıkları Hemşireliği Anabilim Dalı, Aile Hekimliği Anabilim Dalında alanında uzman iki öğretim üyesi ve İngilizce’yi profesyonel düzeyde bilen çevirmen tarafından İngilizce'den Türkçe’ye ayrı ayrı çevrilmiştir. Daha sonra araştırmacılar tarafından bu çeviriler değerlendirilerek, ölçeğin Türkçe formu yeniden düzenlenmiştir. Bu form bağımsız bir dil bilimci uzmanı tarafından tekrar İngilizce'ye çevrilmiştir. Elde edilen ölçek, orjinalini hazırlayan kişiye gönderilerek yorum ve önerileri alınmıştır. Bu öneriler doğrultusunda 8.,10-15. maddelerinde değişiklik yapılmıştır. Yapılan düzeltmeler sonrasında ölçeğin Türkçe'ye uyarlanması ve İngilizce orjinali ile arasında eşdeğerliliğinin sağlanması ile çeviri aşaması son bulmuştur.

\section{Ölçeğin Kapsam Geçerliği}

İngilizce'den Türkçe'ye çevrilen ölçek; kapsam geçerliği için uzman görüşlerine sunulmuştur. Çocuk Sağlı̆̆ı ve Hastalıkları Hemşireliği Anabilim Dalı, Hemşirelik Esasları Anabilim Dalı, Psikoloji Anabilim Dalı, Kadın Sağlığı ve Hastalıkları Hemşireliği Anabilim Dalı, Aile Hekimliği Anabilim Dalı ve Çocuk Sağlığı ve Hastalıkları Anabilim Dalından toplam 9 uzmana gönderilmiştir. Uzmanlardan her bir maddenin uygunluğu ve anlaşllabilirliği açısından değerlendirmesi istenmiştir. Her bir ifadeyi 1-4 puan (1 puan: uygun değil, 2 puan: biraz uygun, 3 puan: uygun, 4 puan: tamamen uygun) arasında puanlamaları ve her madde için görüş ve önerilerini açıkça yazmaları istenmiştir. Uzmanlardan gelen görüşler doğrultusunda maddeler tekrar gözden geçirilerek gerekli değişiklikler yapılmıştır.

Sonuç olarak; uzman kişilerin değerlendirmesi sonucunda uzmanların öneri ve katkıları ile 27 madde olan ölçek maddeleri dil ve ifade yönünden düzeltilmiştir. Değerlendirme sonucunda ölçek madde sayısı Türkiye'de “nurse practitioner” kavramı olmadığı için 6 madde çıkarılarak, 21 madde olarak belirlenmiştir. Ölçek ifadelerinin 10. maddesinden itibaren aynı ifadeler hekim, hemşire, pratisyen hemşire (nurse practitioner) olarak ayrı ayrı olarak yazıldı ̆̆ı için 10a, 10b, 10c ... şeklinde ifade edilmiştir. Bu durumda pratisyen hemşire ifadelerini içeren maddelerin çıkarılması, ölçeğin yapısında bir değişikliğe neden olmamıştır.

Uzman görüşleri değerlendirilirken kapsam geçerlik indeksi kullanılmıştır. Davis tekniğinde ölçekte bulunan her bir madde "1 puan: uygun değil, 2 puan: biraz uygun, 3 puan: uygun, 4 puan: tamamen uygun” olacak şekilde dörtlü yapıda değerlendirme yapılmaktadır. Her madde değerlendirirken “a) Uygun” veya "b) Madde hafifçe gözden geçirilmeli” seçeneğini seçerek işaretleyen uzmanların sayısı toplam uzman sayısına bölünerek her maddeye ilişkin Kapsam Geçerlik İndeksi elde edilmektedir.

Her bir maddeyi değerlendirirken; uygun cevabı
veren uzman

$K G O=\left[\frac{\text { veren uzman }}{\text { toplam uzman }}-1\right]$ formulü ile KGO oranları hesaplanmıştır. Uzman sayısı 9 olduğundan Kapsam Geçerlik Oranı $\frac{\text { sayss }}{2}$

$\mathrm{KGO}=0,75$ belirlenmiştir (11).

Dokuz uzman, 21 maddenin tamamı için çoğunlukla madde uygun ve madde hafifçe gözden geçirilmeli cevaplarını vermiştir. Uzman sayısı 9 olduğundan dolayı 0,75 ten büyük olan KGO oranına sahip maddelerin kapsam geçerliğinin sağlandığı söylenebilir (9). Çalışmamızda Kapsam Geçerlilik İndeksi (KGİ), KGO oranlarının ortalamasında 0,958 bulunmuştur. KGİ>KGÖ $(0,75)$ sonucuna ulaşıldığından ölçeğin kapsam geçerliği istatistiksel olarak anlamlı bulunmuştur.

\section{Araştırmanın Etik Boyutu}

Araştırmanın Türkçe geçerlik ve güvenirliliğinin yapılması için ölçek sahibinden elektronik e-posta yolu ile izin alındıktan sonra etik onayı için; Etik Kurul (No: 02/10/2017-E.14751) onayı, Hastane Yöneticisinden yazılı, ebeveynlerden yazılı ve sözel izin alınmıştır.

\section{Katılımcılara Ait Tanıtıcı Özellikler}

\section{Bulgular}

Araştırmaya $n=210(\%$ 85,4) anne, $n=36(\%$ 14,6) baba katılmıştır. Katılımcıların ( $\mathrm{n}=246)$ yaş ortalaması 29,12 $\pm 6,22$, \%41,9'unun ilköğretim ve lise mezunu, \%67,9'unun çalışmadığı, \%73,2'sinin çekirdek ailede yaşadığ1 ve \% 43,3'ünün ekonomik durumunun gelirin giderden az olduğu saptanmıştır. Katılımcıların \% 76'sı bebeğinin planlı gebelik sonucu olduğunu, \% 93,9'u gebeliğinin spontan olarak oluştuğunu, \%85,8'i doğumda sorun yaşamadığını ve \% 56,5'i sezeryan doğum yaptığını belirtmiştir. Katılımcıların \% 39,8'i ilk bebeği olduğu, \% 53,7'si bebeğinin cinsiyetinin erkek olduğu ve \% 57,7'si bebeklerini sadece anne sütü ile, \%41,1'i ise anne sütü ve mama ile beslediklerini belirtmiştir. Katılımcıların konaklamak için \% 60,6'sının anne otelinde kaldığı ve \%78,9'unun bebeği hakkındaki bilgiyi doktordan aldığı belirlenmiştir.

\section{Yapı Geçerliği}

Ölçeğin yapı geçerliğinin belirlenmesi amacıyla Açıklayıcı Faktör Analizi (AFA) ve Doğrulayıcı Faktör Analizi (DFA) yapılmıştır.

\section{Açıklayıcı Faktör Analizi (AFA)}

Ölçek geçerlik ve güvenirliği amacıyla yapılan bu çalışmada veriler IBM SPSS Statistic 23 paket programına aktarılmıştır. Öncelikle, açıklayıcı faktör analizi uygulandı ve faktör çıkarma yöntemi olarak "Temel Bileşenler Yöntemi” tercih edilmiştir. Ölçek uyarlama çalışmalarında, ölçeğin faktör yapısı belli olduğu için AFA uygulanmadan DFA yapılabilemektedir. Ancak, bu 
çalışmada pratisyen hemşire ifadelerinin yer aldığı maddeler ölçekten çıkarıldığı için faktör yapısında değişiklik olup olmadığını belirlemek için AFA yapılmıştır.

Faktör yapısının incelenebilmesi için örneklem yeterliliğinin belirlenmesi amacıyla Kaiser-Meyer Olkin (KMO) testi ve ölçeğe faktör analizi yapılıp yapılamayacağını belirlemek için ise Barlett’s Testi uygulanmıştır (11).

Tablo 1. EPİA-YYBய̈ Ölçeği’nin Kaiser Meyer Olkin Değeri (KMO) ve Bartlett Küresellik Testi Sonuçları

\begin{tabular}{lll}
\hline Kaiser Meyer Olkin (KMO) & & 0,823 \\
\hline & $X^{2}$ & 3068,080 \\
\cline { 2 - 3 } Bartlett Küresellik Testi & $\mathrm{sd}$ & 120 \\
\cline { 2 - 3 } & $\mathrm{p}$ & $0,000^{*}$
\end{tabular}

Tablo 1 incelendiğinde; 21 maddeden oluşan yapıya uygulanan Açıklayıcı Faktör Analizi sonucunda KMO değeri 0,823 olarak bulunmuştur. Böylece örneklem sayısının, verilere faktör analizi uygulayabilmek için yeterli olduğu görülmüştür. Bartlett Küresellik testi sonucuna göre, değişkenler arasında anlamlı düzeyde yüksek ilişkiler bulunmuştur. Ölçeğin faktör analizi uygulamak için uygun olduğu sonucuna ulaşılmıştır $(p<0,05)$. "Genel Engeller” alt boyutu toplam varyansın \%26,013'ünü, "Kişisel İlişkiler" alt boyutu \%21,047'sini ve "Katılım” alt boyutu ise toplam varyansın \%20,525'ini açıklamaktadır. "Genel Engeller", "Kişisel İlişkiler” ve "Katılım” alt boyutları birlikte toplam varyansın \%67,585'ini açıklamaktadır. EPİA-YYBÜ Ölçeği'nde 1, 10, 12, 13. maddeler kavramsal olarak farklı boyutlara yüklendiği, 9.madde farklı boyutlara yüklendiği için analiz dışında bırakılmıştır. Bu nedenle 27 olan madde sayısı 16'ya düşürülmüştür.

\section{Doğrulayıcı Faktör Analizi}

On altı madde, üç faktörden oluşan yapıyı doğrulamak için kurulan ölçüm modeli analiz edilmiştir. Analiz sonucunda modelin yeterli uyum göstermediği görüldüğünden model iyileştirme çalışmaları yapılmıştır. Öncelikle modifikasyon indeksleri tablosuna bakılarak modelde yapılacak olası değişiklikler için ki kare düşüş değerleri ("M.I.” değerleri) incelenmiştir. En yüksek "M.I." değerinin göstermiş olduğu modifikasyon, kavramsal olarak uygun olduğu durumlarda bağlanarak model yürütülmüştür. Modelin 16 madde, 3 alt boyut ile doğrulandığı görülmüştür. Doğrulanan ölçüm modeli aşağıda sunulmuştur (Şekil 1).

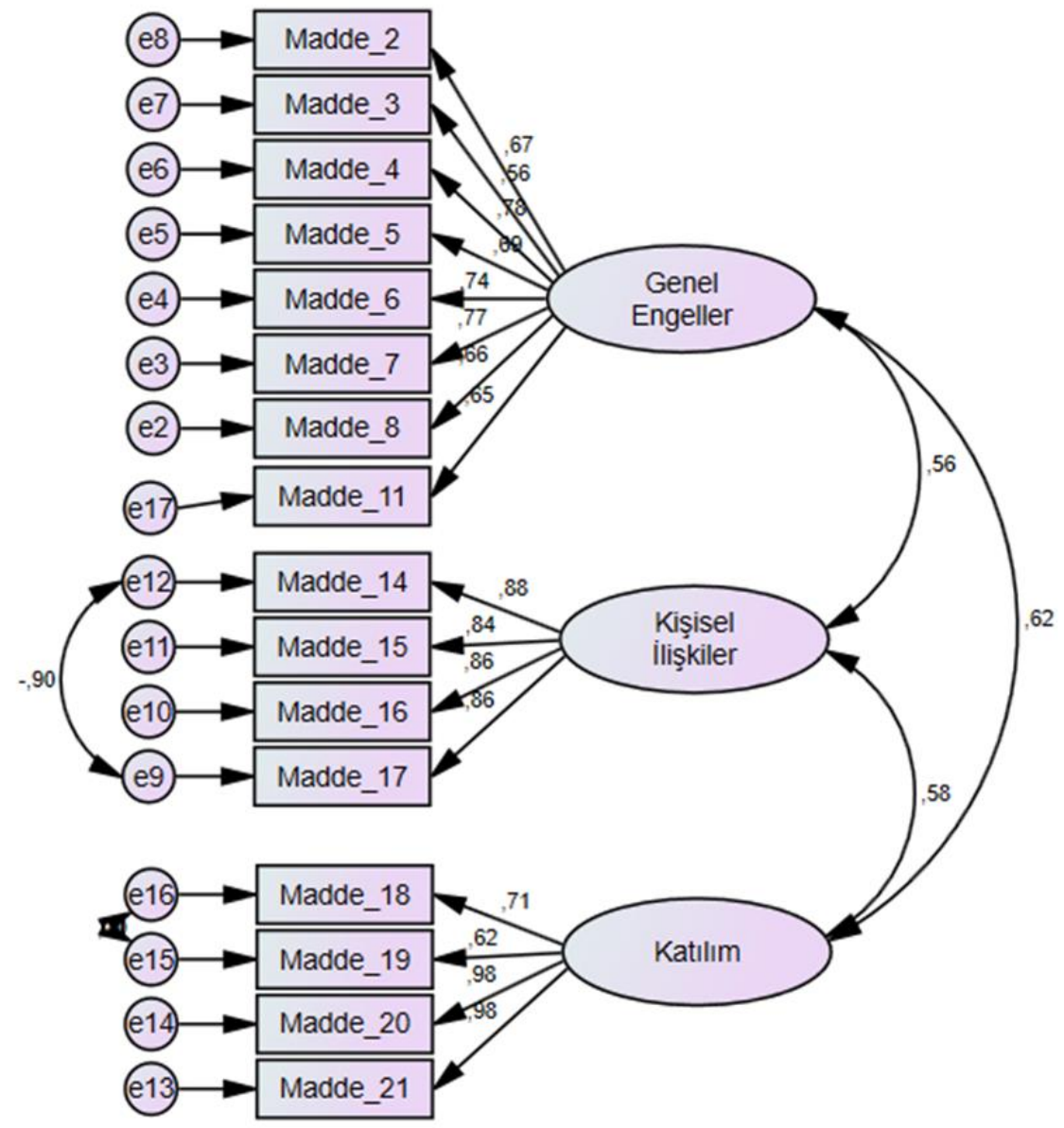

\section{Şekil 1. EPİA-YYBÜ Ölçeği'nin Ölçüm Modeli}

Şekil 1'deki ölçüm modeline göre, 16 madde ile doğrulanan ölçüm modelinin hangi maddelerden oluştuğu ve tek yönlü oklar üzerindeki yollara ait standardize regresyon katsayıları yani başka bir ifadeyle faktör yükleri görülmekte olup 0,56'nın altında faktör yükü olmadığı belirlenmiştir. 
Tablo 2. EPİA-YYBÜ Ölçeği’nin Maddelerine İlişkin DFA Sonucu Faktör Yükleri

\begin{tabular}{|c|c|c|c|}
\hline & Genel Engeller & Kişisel İlişkiler & Katılım \\
\hline Madde 2 & 0,672 & & \\
\hline Madde 3 & 0,559 & & \\
\hline Madde 4 & 0,783 & & \\
\hline Madde 5 & 0,690 & & \\
\hline Madde 6 & 0,742 & & \\
\hline Madde 7 & 0,772 & & \\
\hline Madde 8 & 0,664 & & \\
\hline Madde 11 & 0,647 & & \\
\hline Madde 14 & & 0,647 & \\
\hline Madde 15 & & 0,883 & \\
\hline Madde 16 & & 0,836 & \\
\hline Madde 17 & & 0,861 & \\
\hline Madde 18 & & & 0,706 \\
\hline Madde 19 & & & 0,615 \\
\hline Madde 20 & & & 0,976 \\
\hline Madde 21 & & & 0,980 \\
\hline
\end{tabular}

Tablo 2'de 16 maddeden oluşan EPİA-YYBÜ Ölçeği’nin alt boyutlarında hangi maddelerin yer aldığı ve her bir maddenin faktör yükü bulunmakta olup; ölçek maddelerinin 0,559- 0,980 faktör yükü arasında olduğu saptanmıştır.

Tablo 3. Ölçüm Modelinin Uyum İndeks Değerleri ve İyi Uyum Değerleri

\begin{tabular}{lcc}
\hline & Uyum İndeks Değerleri & Kabul Edilebilir Uyum Değerleri \\
\hline $\boldsymbol{\chi}^{2} / \mathbf{s d}$ & 3,068 & $\leq 5$ \\
GFI & 0,873 & $\geq 0,85$ \\
CFI & 0,901 & $\geq 0,85$ \\
NFI & 0,892 & $\geq 0,85$ \\
TLI & 0,898 & $\geq 0,85$ \\
RMSEA & 0,078 & $\leq 0,08$ \\
SRMR & 0,041 & $\leq 0,10$ \\
\hline
\end{tabular}

Tablo 3 incelendiğinde; EPİA-YYBÜ Ölçeği’nin doğrulayıcı faktör analizi uyum indeksi sonuçlarının kabul edilebilir sınırlarda olduğu bulunmuştur.

\section{Ölçek Güvenirlik Çalışmaları}

Cronbach alfa iç tutarlılık anlamında güvenirlik katsayısı

Alfa katsayısı, ölçek maddelerinin, homojenliğinin bir ölçüsüdür. Ölçeğin alfa katsayısı ne kadar yüksek ise "ölçek maddelerin birbiriyle tutarlı ve aynı özelliğin öğelerini yoklayan maddelerden oluştuğu ya da tüm maddelerin birlikte çalıștığı” șeklinde açıklama yapılabilir. Sonuç olarak alfa katsayısı yüksekse yanıtlayıcıların ölçek maddelerine verdikleri yanıtlar birbirleri ile o derece tutarlı olmakta ve ölçek ile ilgili kavramsal yapıdan ayrılmayan maddelerden oluşmaktadır (11).

Uygulanan Cronbach Alfa analizi sonucunda 16 maddeden oluşan EPİA-YYBÜ Ölçeği'nin 8 maddeden oluşan “Genel Engeller” alt boyutu, 4 maddeden oluşan "Kişisel İlişkiler" alt boyutu ve 4 maddeden oluşan "Katılım” alt boyutlarının güvenirlik seviyelerinin yüksek olduğu görülmüştür $(\alpha>0,700)$ (Tablo 4).

Tablo 4. EPİ-YYBÜ Ölçeği ve Alt Boyutları İçin Güvenirlik Katsayısı ve Test-Tekrar Test Arasındaki Uyum Sonuçları

\begin{tabular}{lcccc}
\hline & Madde Sayısı & $\begin{array}{c}\text { Cronbach's } \\
\text { Alfa }\end{array}$ & ICC * & $\begin{array}{c}\text { \%95 Güven Aralığında } \\
\text { ICC Değerleri }\end{array}$ \\
\hline Genel Engeller & 8 & 0,876 & 0,874 & $(0,560-0,915)$ \\
Kişisel İlişkiler & 4 & 0,901 & 0,644 & $(0,192-0,843)$ \\
Katılım & 4 & 0,914 & 0,763 & $(0,514-0,906)$ \\
Ölçek Toplam & 16 & 0,926 & 0,757 & $(0,441-0,891)$ \\
\hline
\end{tabular}

*ICC: Sınıf İçi Korelasyon 
Araştırma

\section{Test-Tekrar Test Güvenirliği}

EPİA-YYBÜ Ölçeği’nin kararlılığını ölçmek için 25 katılımcıya iki hafta sonra ölçek tekrar uygulanmıştır. Uygulanan tekrar test ile ilk test arasında yüksek uyum olduğu görülmüştür (ICC=0,757). Buna göre EPİA-YYBÜ Ölçeği ve alt boyutlarında zamana bağlı bir değişim oluşmadığı belirlenmiştir (Tablo 4).

\section{Tartıșma}

YYBÜ'nde bebeği yatan ebeveynlerin diğer kliniklerde yatan ailelere göre birtakım gereksinimleri öncelik taşımaktadır. Bunlar, fizyolojik gereksinimler (yeme-içme, uyku vb), sosyal destek alabilme, güven duyma, çocuğunun bakımına katılabilme, bilgi alabilme ve iletişim gibi temel gereksinimlerdir (13). Ailelerin bebeklerinin bakımına katılabilmeleri, onların içinde yaşadıkları sürece uyum sağlamaları, bebeğin sağlığı ile ilgili daha sağlıklı karar vermeleri ve sağlık ekibi ile iletişim içinde olmaları sağlanabilir (14). Konukbay ve ark.'nın yaptıkları bir araştırmada ailelerin \%17,8 sağlık ekibi üyeleri ile iletişimde sorun yaşadıkları belirlenmiştir (15). Literatürde hemşirelerin YYBÜ'sinde bebeği yatan ebeveynler için duygusal olarak destekleyici iletişimin çoğunu sağladığına ve bu tür bir desteğin ebeveynler tarafından değerli olduğuna dair kanıtlar vardır (16). Montirosso ve ark.'nın YYBÜ'sinde bebeği yatan ebeveynlerin bilgi ihtiyacının dikkate alınması gerektiğini bildirmiştir. Ebeveynler için yeterli bilgiyi sağlamak ve onların duygularını sağlık personelleri ile paylaşabilmeleri için sistematik programlara ihtiyaç duyulduğunu öne sürmektedir (17). Yapılan bir çalışmada; sağlık personellerinin ebeveynleri bilgilendirmek için konuşmalarının, ebeveynler üzerinde sağlık elamanlarının empatik ve anlayışlı olduğu algısının önemli bir etkisi olduğunu göstermiştir (18). Öte yandan, personel ve ebeveynler arasındaki temas eksikliği, ebeveynlerin kaygı ve dışlanma duygularını güçlendirebilir. Bu çalışma ile EPİA-YYBÜ ölçeğinin kültürel adaptasyonunu doğru ve güvenilir bir şekilde ölçebilmek için Türkçe'ye kazandırılması amaçlandı. YYBÜ’nde ebeveyn-personel (doktor, hemşire, diğer personel) iletişimi algılarının değerlendirilmesine yönelik geçerlik ve güvenirliği yapılmış herhangi bir ölçeğe rastlanılmamıştır.

Bir ölçme aracında olması gereken teknik özellikler arasında güvenirlik ve geçerlik ilk sırayı almaktadır. Geçerlik; ölçeğin ölçülmek istenen şeyi ölçme derecesi ya da ölçüm aracının ölçülmek istenen özelliğe uygun olması olarak ifade edilmektedir. Başka bir ifade ile ölçüm verilerinin gerçekten ölçülmek istenen özelliği yansıtıp yansıtmadığı şeklinde belirtilmiştir. Güvenirlik, kişilerin test maddelerinin her birine verdikleri yanıtlar arasındaki tutarlılık olarak açıklanmakta olup; bir testin veya ölçeğin ölçmek istediği özelliği ne derece doğru ölçtüğü ile ilgilidir. Ölçeğin geçerliğini sınamak için kapsam geçerliği ve yap1 geçerliği yapılmaktadır. Kapsam geçerliği ölçek maddelerinin, ölçülmek isteneni yeterli düzeyde karşılayıp karşılamadığını göstermektedir. Uzman görüşü almak kapsam geçerliğini değerlendirmede kullanılan bir yöntemdir (11).

"EPİA-YYBÜ Ölçeği”" taslağı maddelerinin uygunluğunun değerlendirilmesi için uzman görüşüne sunularak kapsam geçerliği test edildi. Uzmanlardan gelen değerlendirmeler doğrultusunda her bir ölçek maddesine ait KGO hesaplandı. Uzman sayısı 9 olduğundan dolayı 0,75 'ten büyük olan KGO oranına sahip maddelerin kapsam geçerliğinin sağlandığ1 söylenebilir (11). KGİ, KGO oranlarının ortalaması hesaplanarak 0,958 bulundu. KGİ>KGÖ $(0,75)$ olduğundan tüm ölçeğin kapsam geçerliğinin istatistiksel olarak anlamlı olduğu saptandı.

Yapı geçerliğinin değerlendirilmesinde sık kullanılan yöntemlerden biri olan faktör analizi, ölçeğin maddelerin farklı boyutlar altında toplanıp toplanmayacağını incelemek amacıyla yapılmaktadır (19). Bu çalışmada; ölçeğin yapı geçerliği bölümünde AFA ve DFA yapıldı. Öncelikli olarak ölçeğin örneklem büyüklüğünün yeterli olup olmadığını gösteren KMO testi ve ölçeğin faktör analizi için uygun olup olmadığını belirleyen Bartlett Testi uygulandı. KMO değerine bakılarak örneklem büyüklüğünün yeterliliği değerlendirilmektedir. KMO değeri 0,90-1,00 arasında ise mükemmel, 0,80-0,89 arasında olduğunda çok iyi, 0,70-0,79 arasında olduğunda iyi, 0,60-0,69 arasında olduğunda orta, 0,50-0,59 arasında olması örneklem büyüklüğünün zayıf olduğunu göstermektedir. Değerin 0,50’nin altında olması örneklem büyüklüğünün kabul edilemez olduğunu belirtmektedir (11). Bu çalışmada KMO değerinin 0,823 bulunması örneklem büyüklüğünün yeterlilik bakımından "çok iyi” düzeyde olduğunu göstermektedir. Ayrıca örneklemin faktör analizi için uygunluğunu değerlendirmek amacıyla yapılan Bartlett Küresellik Testi sonucunun istatistiksel açıdan anlamlı olması gerekmektedir (11). Çalışmada Bartlett Küresellik Testi analizi sonucu $\mathrm{X}^{2}=3068,08, \mathrm{p}=0,000$ şeklinde olup anlamlı bulunmuştur. Bu sonuçlar örneklem büyüklüğünün faktör analizi için uygun olduğunu göstermektedir (11).

Doğrulayıcı faktör analizi, bir faktörü oluşturan maddelerin faktörle ilişkisinin yeterli olup olmadığını değerlendirmektedir (11). Literatürde AFA oluşturulan faktör yüklerinin toplam varyansı açıklama oranı \%40-\%60 arasında olmasının yeterli kabul edileceği, faktör yük değeri 0,50’un altında olan maddelerin analizden çıkartılması gerektiği belirtilmiştir (11). Bu çalışmada "EPİA-YYBÜ Ölçeği” taslağının AFA sonuçları incelendiğinde; "Genel Engeller" alt boyutu toplam varyansın \%26,013'ünü, “Kişisel İlişkiler” alt boyutu \%21,047'sini ve "Katılım” alt boyutu ise toplam varyansın \%20,525'ini açıklamaktadır. "Genel Engeller", "Kişisel İlişkiler” ve "Katılım” alt boyutları birlikte toplam varyansın \%67,585'ini açıkladığı bulunmuştur.

Ölçekte 1,10, 12, 13 maddeler kavramsal olarak farklı boyutlara yüklendiği için, 9. madde farklı boyutlara (0,40’ın üzerinde) yüklendiği için analiz dışında bırakılmıştır. Bu nedenle 21 olan madde sayısı 16'ya düşürülmüştür. On altı maddeden oluşan yapıyı doğrulamak için kurulan ölçüm modeli analiz edilmiştir. Modelin Açıklayıcı Faktör analizini 16 madde 3 alt boyut ile doğruladığı görülmüştür. Yapılan faktör analizinde ölçekte kalan 16 maddenin faktör yüklerinin 0,55- 0,98 arasında olduğu görülmüştür (Tablo 3). Bu değerlerin belirtilen referans değerin üzerinde olması yapı geçerliğinin yeterli olduğunu göstermiştir.

Ölçeğin güvenirliğinin hesaplanmasında Cronbach's alfa güvenirlik katsayısı ve test tekrar test yöntemi kullanılmıştır. Cronbach's alfa güvenirlik katsayısının yüksek olması ölçek maddelerinin birbiriyle tutarlı olmasının (iç tutarlığı) ve aynı özelliği ölçtüğünün göstergesidir (9). Ölçme aracının güvenirlik katsayısının olabildiğince 1'e yakın olması istenmektedir. Alfa katsayısına bağlı olarak ölçeğin güvenirliği; 0,40'dan küçük ise ölçme aracı güvenilir değil, 0,40-0,59 arası ise ölçeğin güvenirliği düşük, 0,60-0,79 arası ise ölçek oldukça güvenilir, 0,80-1,00 arası ise ölçek yüksek derecede güvenilir şeklinde değerlendirmektedir (18). 
Araştırma

Uygulanan Cronbach Alfa analizi sonucunda 16 maddeden oluşan EPİA-YYBÜ Ölçeğinin, geneline ait güvenirlik katsayısı 0,92, “Genel Engeller” alt boyutu için 0,87, "Kişisel İlişkiler” alt boyutu için 0,90 ve "Katılım” alt boyutu için Cronbach alfa iç tutarlık katsayısının 0,91 olarak bulundu. Reid ve ark.'nın (1) yaptıkları ölçeğin orjinalinde çalışmaya göre güvenirlik katsayısı birinci çalışma grubunda, tüm ölçek için= 0,89, Genel Engeller $=0,91$, Kişisel İlişkiler=0,86, Katılım=0,84 olarak bulunmuş olup ikinci çalışma grubunda tüm ölçek için=0,86, Genel Engeller=0,89, Kişisel İlişkiler=0,84, Katılım=0,83 olarak rapor edilmiştir. İran' da yapılan çalışmada da ölçeğin tümü için Cronbach alfa değeri 0,89 bulunmuştur (7). Yapılan bu çalışma ile literatür benzer sonuçlar göstermektedir. Ayrıca sonuçlar ölçeğin yüksek derecede güvenilir olduğunu desteklemektedir (11).

En sık kullanılan güvenirlik yöntemlerinden bir diğeri ise test tekrar test analizidir. Test tekrar test analizi ile ölçeğin tekrarlayan uygulamalarda tutarlı olması ve zamana göre değişmezliği incelenmektedir (19). Test-tekrar test yönteminde ölçeğin aynı bireylere, aynı koşullarda ve önemli derecede hatırlamaları önleyecek kadar uzun, fakat ölçülecek özellikte önemli değişmeler olmasına izin vermeyecek kadar kısa bir zaman aralığında iki kez uygulanması önerilmektedir (11). Her iki uygulamadan alınan puan ortalamalarının karşılaştırılarak iki ölçüm arasında istatistiksel açıdan anlamlı farkın olmaması, sonuçların zamana karşı değişmeyerek benzer ve güvenilir olduğunu göstermektedir (20). Bu amaçla iki ölçüm arasındaki zaman aralığı genellikle iki-üç ve dört-altı hafta arasında olmalıdır (20). Bu çalışmada ise ölçek literatüre uygun olarak iki hafta arayla 25 kişiye uygulanmıştır. Uygulanan tekrar test ile ilk test arasında yüksek uyum olduğu görülmektedir (ICC=0,757). Tekrar test ile ilk test arasındaki korelasyon katsayıları; 8 maddeden oluşan "Genel Engeller" alt boyutunda: 0,874; 4 maddeden oluşan "Kişisel İlişkiler" alt boyutunda r: 0,644; 4 maddeden oluşan "Katılım” alt boyutunda r: 0,763 bulunmuştur. Ölçeğin orijinal formunda tekrar test ile ilk test arasındaki korelasyon katsayıları; "Genel Engeller" alt boyutunda: 0,51; 4 maddeden oluşan "Kişisel İlişkiler” alt boyutunda r: 0,46; 3 maddeden oluşan "Katılım” alt boyutunda r: 0,46 bulunmuştur (1). Buna göre EPİAYYBÜ ölçeğinde ve alt boyutlarında zamana bağlı bir değişim oluşmamakta ve güvenilir olduğuna işaret etmektedir.

\section{Kisıtlılıklar}

Babaların gündüz mesai saatlerinde çalışıyor olmasından dolayı araştırmaya katılan baba sayısının az olması çalışmamızın kısıtlılı̆̆ıdır.

\section{Sonuçların Uygulamada Kullanımı}

YYBÜ'sinde bebekleri yatan ebeveynlerin stres yaşadıkları bilinmektedir. Ailelerin desteklenmesi, streslerinin azaltılması ve iyilik hallerinin yükseltilmesi gereklidir. İyilik hallerini artırmada bütün sağlık profesyonellerinin rolü vardır. Bu çalışma ile literatüre kazandırılan “Yenidoğan Yoğun Bakım Ünitesi Ebeveyn- Personel İletişim Algıları Ölçeği” YYBÜ’nde bebeği yatan ebeveynler ile personel arasındaki iletişim algılarının belirlenmesi amacıyla kullanılabilecek yeterli geçerlik ve güvenirlik göstergelerine sahip bir ölçüm aracıdır.

\section{Bilgilendirme}

Yazarların katkı oranı beyanı şöyledir: Fikir/Kavram: HZ, NÇ; tasarım: HZ, ÖT, ÖKS; denetleme/danışmanlık: HZ, NÇ; veri toplama ve işleme: HZ, ÖT, ÖKS; analiz ve yorum: HZ, ÖT, ÖKS, NÇ; kaynak taraması: HZ, ÖT, ÖKS; makalenin yazımı: HZ, ÖT, ÖKS; eleştirel düşünme: HZ, NÇ; araştırmanın bütçesi: HZ, ÖT, ÖKS.

Araştırma ile ilgili herhangi bir projeden ya da firmadan destek alınmamıştır. Araştırma bütçesi, araştırmacılar tarafından karşılanmıştır. Yazarlar arasında herhangi bir çıkar çatışması yoktur. Ayrıca sorumlu olduğumuz araştırmada herhangi bir firma ile çıkar ilişkisi yoktur. Araştırmanın yapılabilmesi için Tıp Fakültesi Girişimsel Olmayan Etik Kurulu'ndan izin alınmıştır (02.10.2017 tarihli ve 169 sayılı karar).

Araştırmaya katılan tüm ebeveynlere teşekkür ederiz.

\section{Teșekkür}

\section{Kaynaklar}

1. Reid T, Bramwell R, Booth N, Weindling M. Perceptions of parent-staff communication in neonatal intensive care: The development of a rating scale. J Neonatal Nurs 2007;13: 24-35.

2. Işıklı İE. Hastane çalışanlarının meslek etiği hakkındaki görüşlerinin ve etik sorunlarının incelenmesi. ESOSDER 2018; 17(66): 861-873.

3. Babadağlı B, Erim SE, Erdoğan S. Hekimlerin ve hemşirelerin hastayla iletişim becerilerinin değerlendirilmesi. Fırat Sağlık Hizmetleri Dergisi 2006;1(3):59.

4. İnal S, Akgün M. Hastanede yatan çocukta terapötik iletişim. Atatürk Üniv. Hemşirelik Yüksekokulu Dergisi 2003; 6(2): 68.

5. Parlayan MA, Dökme S. Özel hastanelerdeki hemşire ve hastaların iletişim seviyelerinin değerlendirilmesi: Bir hastane örneği. KSÜ Sosyal Bilimler Dergisi 2016; 13 (2): 1-20.

6. Şen HT, Yılmaz FT, Ünüvar ÖP. Hizmet içi eğitim hemşirelerinin iletişim beceri düzeyleri. Psikiyatri Hemşireliği Dergisi 2013; 4(1): 13-20.

7. Fegran L, Helseth S, Fagermoen MSA. Comparison of mothers' and fathers' experiences of the attachment process in a neonatal intensive care unit. J Clin Nurs 2008; 17:810-816.

8. Şahin NH, Oskay Ü. Prematüre bebekleri yenidoğan yoğun bakım ünitesinde yatan ebeveynlerde ortaya çıkan stresörler. Çocuk Dergisi 2008; 8(2):108-113. 


\section{Araştırma}

9. Hasanpour M, Alavi M, Azizi F, Als H, Armanian AM. Iranian parent-staff communication and parental stress in the neonatal intensive care unit. J Educ Health Promot 2017; 6: 49.

10. Turan T, Başkale H, Öncel G. Determining the psychometric properties of the turkish version of the nurse-parent support tool and the stress levels of parents of premature infants hospitalized in the neonatal intensive care unit. Clin Nurse Spec 2016;30(3): E1-10.

11. Alpar R. Spor, Sağlık ve Eğitim Bilimlerinden Örneklerle Uygulamalı İstatistik ve Geçerlik-Güvenirlik-SPSS'de Çözümleme Adımları ile Birlikte. 3. Baskı, Ankara Detay Yayıncılık, 2014; 529.

12. Arlı M, Nazik H. Bilimsel Araştırmaya Giriş. Ankara: Gazi Kitabevi. (2001). P: 77.

13. Çalışır H, Şeker S, Güler F, Anaç GT, Türkmen M. Yenidoğan yoğun bakım ünitesinde bebeği yatan ebeveynlerin gereksinimleri ve kaygı düzeyleri. C.Ü. Hemşirelik Yüksekokulu Dergisi 2008; 12(1): 31-44.

14. Beal JA, Quinn M. The nurse practitioner role in the nicu as perceived by parents. MCN The American Journal of Maternal/ Child Nursing 2002;27(3): 183-188.

15. Konukbay D, Arslan F. Yenidoğan yoğun bakım ünitesinde yatan yenidoğan ailelerinin yaşadıkları güçlüklerin belirlenmesi. Anadolu Hemşirelik ve Sağlık Bilimleri Dergisi 2011; 14(2): 16-22.

16. Cox C, Bialoskurski M. Neonatal intensive care: communication and attachment. Br J Nur 2001; 10(10): 668-676.

17. Montirosso R, Provenzi L, Calciolari G, Borgatti R. Measuring maternal stres and perceived support in 25 italian nicus. Acta Paediatr 2012; 101: 136-142.

18. Weiss S, Goldlust E, Vaucher YE. Improving parent satisfaction: an intervention to increase neonatal parent-provider communication. J Perinatol 2010; 30(6): 425-430.

19. Karakoç FY, Dönmez Y. Ölçek geliştirme çalışmalarında temel ilkeler. Tıp Eğitimi Dünyası 2014; 13(40): 39-49.

20. Esin MN. Hemşirelikte Araştırma. Veri Toplama Yöntem ve Araçları, Veri Toplama Araçlarının Güvenirlik ve Geçerliliğii. I. Bask1, İstanbul: Nobel Tıp Kitapevi, 2014; 223-231. 